\title{
Programas de Pós-graduação em Química no Brasil
}

Pesquisa, desenvolvimento e inovação - PDI - são requisitos fundamentais para o desenvolvimento de qualquer país e há uma relação íntima entre o nível de desenvolvimento de uma sociedade e sistemas científicos e tecnológicos que proporcionem um suprimento contínuo de recursos humanos e produtos de alta tecnologia.

No Brasil, PDI está fortemente ligado aos esforços dos programas de pós-graduação e, embora atingindo uma pequena parcela de um país continental extremamente heterogêneo, atingimos, em 2010, o considerável número de 2.840 programas de pós-graduação com Mestrado e/ou Doutorado. Nesse mesmo ano, 39.590 alunos de pós-graduação terminaram o Mestrado e 11.314, o Doutorado.

Esses números evidenciam um aumento considerável, embora se refiram a uma pequena parcela da população. Considerando-se a publicação de artigos, em 2009, chegamos a 31.158 publicações, o que representa $2,7 \%$ da produção científica mundial. Vale a pena ressaltar que, em 1970, o Brasil publicou 64 artigos, 0,019\% da produção científica mundial. ${ }^{1}$

Em Química, temos 58 programas de pósgraduação, a maioria deles oferecendo Mestrado e Doutorado e apenas dois oferecendo cursos de Mestrado Profissional. Esses programas estão espalhados por todo o território brasileiro, mas relativamente concentrados no Sul e Sudeste e relativamente escassos no Norte e Centro-Oeste, com quatro estados (Acre, Amapá, Rondônia e Tocantins) sem nenhum programa. Entre 2007 e 2009 , esses programas formaram, por ano, cerca de 800 Mestres e 450 Doutores, o que reflete o esforço de 1.250 docentes. Durante esse período de três anos, 10.475 artigos foram publicados, com $62 \%$ deles apresentando, pelo menos, um aluno como co-autor.
Todos esses aspectos são continuamente discutidos e, a cada três anos, a CAPES avalia todos os programas de pós-graduação, que, atualmente, englobam 3.700 programas dentro do Sistema Nacional de Pós-Graduação. A avaliação tem, pelo menos, duas funções principais: determinar onde estamos e possibilitar reflexões sobre as ações que nos levarão aonde queremos chegar.

O processo de avaliação engloba cinco eixos principais: (1) Proposta do Programa; (2) Corpo Docente; (3) Corpo Discente; (4) Produção Intelectual e (5) Integração com a Sociedade. Em cada eixo, os parâmetros são medidos com base em dados qualitativos e quantitativos. Esse é um processo complexo que envolve a comunidade científica de cada e de todos os campos de conhecimento.

O processo é realmente difícil, pois a pósgraduação nas diferentes regiões do país apresenta especificidades que são cuidadosamente consideradas, daí a organização do trabalho em comissões com membros de todas as regiões. $\mathrm{Na}$ área de Química, temos encontros anuais com Coordenadores de cada programa de pós-graduação e todos os parâmetros aplicados são discutidos, sendo suas implicações integralmente consideradas. Os objetivos principais são: manter a qualidade daqueles programas que, ao longo dos anos, alcançaram um padrão de qualidade internacional e, ao mesmo tempo, criar estratégias para ajudar o desenvolvimento dos programas em processo de implementação e consolidação.

A sistematização do processo de avaliação nas três últimas décadas foi um dos fatores fundamentais para a evolução do Sistema Nacional de Pós-Graduação e uma diretriz importante para o estabelecimento de metas e objetivos. 
Atualmente estamos em pleno processo de avaliação de outro período de três anos: 2010-2012 e a CAPES está mais uma vez coordenando toda a estrutura com uma equipe de 1.200 consultores em 48 áreas. No que concerne à Química, uma Comissão de 22 membros, representando todas as regiões do Brasil, atua no processo e conta com o importante subsídio da comunidade ao longo dos últimos anos. Novamente, os objetivos são evidenciar os avanços no período e estabelecer as diretrizes para o desenvolvimento contínuo.

Vislumbrando o futuro, precisamos discutir o papel dos Cursos de Mestrado Profissional na área de Química. Até o momento, temos dois cursos relativamente recentes, ambos localizados no Estado São Paulo, e precisamos discutir se devemos intensificar nossos esforços para continuar apoiando o desenvolvimento de nossa indústria química.

Recentemente, Wongtschowski enfatizou que não existe país desenvolvido sem uma forte indústria química. ${ }^{2}$ Ele também salientou que, apesar de ter atingido uma receita de 159 bilhões de dólares, a indústria química brasileira apresentou, em 2011, um déficit comercial de 26,9 bilhões de dólares. Apenas para apresentar um panorama geral sobre a evolução dos Cursos de Mestrado Profissional em todas as áreas, há atualmente, no Brasil, 547 deles, com uma taxa de crescimento de $146 \%$ nos últimos cinco anos. ${ }^{3}$

Pinto também abordou a urgência da discussão acerca de um programa de pós-graduação profissional para a formação de professores. ${ }^{4} \mathrm{O}$ momento é apropriado para aprofundar essas reflexões e ampliar nossas ações.

Todos esses esforços para avançar devem estar intimamente conectados com a consolidação do sistema brasileiro de educação primária e secundária. É difícil tentar predizer o futuro, mas todos nós concordamos que não há futuro sem educação de qualidade.

\section{Joaquim A. Nóbrega \\ Editor do JBCS}

\section{Referências}

1. de Almeida, E. C. E.; Guimarães, J. A.; A pósgraduação e a evolução da produção científica brasileira; Editora SENAC, São Paulo, Brasil, 2013.

2. Wongtschowski, P.; J. Braz. Chem. Soc. 2012, 23 , 1957.

3. Oliveira, F. C. C.; Comunicação Pessoal.

4. Pinto, A. C.; J. Braz. Chem. Soc. 2012, 23, 1410. 


\section{Graduate Programs in Chemistry in Brazil}

Research, development and innovation, R\&D\&I, are critical requirements for the advancement of every country and there is an intimate relationship between the development status of a society and the well-established scientific and technological systems which provide continuous supply of human resources and high-technology products.

In Brazil R\&D\&I are strongly linked to efforts in graduate programs and despite reaching a small fraction of an extremely heterogeneous and continental country, in 2010, we reached significant numbers of 2,840 graduate programs with Masters and/or Doctorate degrees. In this same year 39,590 graduate students finished their Masters Course and 11,314 graduate students finished their Doctorate Course.

These numbers show a consistent increase, but again they only reach a small fraction of the population. Taking into account the publication of papers, in 2009, Brazil reached a total of 31,158 publications, which represents $2.7 \%$ of the world output in sciences. It is worth to point out that in 1970, Brazil published 64 papers, totalizing $0.019 \%$ of the world output in sciences. ${ }^{1}$

In Chemistry we have 58 graduate programs with most of them offering Masters and Doctorate degrees, and only two of them offering courses in Professional Masters. These programs are spread throughout Brazil's territory, but they are relatively concentrated in the South and Southeast and relatively scarce in the North and Central-West with four states (Acre, Amapá, Rondônia and Tocantins) without any program. In the period of 2007-2009, these programs formed about 800 Masters and 450 Doctors per year reflecting the efforts of 1,250 professors. In this threeyear period, 10,475 papers were published with $62 \%$ of them presenting at least one student as coauthor.
All of these aspects are continuously assessed and after each three-year period the Brazilian Federal Agency for Support and Evaluation of Graduate Education (CAPES) is committed to the evaluation of all graduate programs which nowadays comprehend 3,700 graduate programs as the National System of Graduate Education. Evaluation has at least two crucial routes: to measure where we are and to think about actions to lead us where we should go.

There are five major axes in the evaluation process: (1) Program Proposal; (2) Faculty; (3) Students; (4) Intellectual Output and (5) Integration with Society. Parameters are measured in each axe based on qualitative and quantitative data. This is a complex process involving the scientific community in each and every field of knowledge.

Surely the process is difficult and graduate programs in different country regions present specificities that are carefully considered especially by organizing the work in committees with members from all regions. In the Chemistry area we have annual meetings with Coordinators of each graduate program and all applied parameters are discussed and their implications are fully considered. The main goals are to keep healthy the programs that along years have reached an international degree of quality and at the same time to create strategies to help the development of programs in the process of implementation and consolidation.

The systematization of the evaluation process in the last three decades was one of the cornerstones for the evolution of the National System of Graduate Education and an important guideline for establishing targets and goals.

Nowadays we are going through the evaluation process for another three-year period, 2010-2012, and 
CAPES is again coordinating the whole structure with a team of around 1,200 consultants in 48 major areas. In the Chemistry area a Committee of 22 members representing all Brazilian regions is working in the process with a strong feedback of the community along these last years. Once again, the goals are to evidence the evolution in the period and to set guidelines for continuous development.

Looking to the future we need to discuss the role of Professional Masters Courses in the Chemistry area. So far, we have two relatively recent courses, both in institutions located in São Paulo State and we must discuss whether we should strengthen our efforts to keep supporting the development of our chemical industry.

Recently Wongtschowski emphasized that there is no developed country without a strong chemical industry. ${ }^{2} \mathrm{He}$ also highlighted that, despite reaching sales of US\$ 159 billion, the Brazilian chemical industry had a trade deficit of US\$ 26.9 billion in 2011. Just to provide a general view about the evolution of Professional Masters Courses in all areas, there are now 547 Professional Masters Courses in Brazil with a growing rate of $146 \%$ in the last five years. ${ }^{3}$

Additionally, Pinto has suggested the emergency of the discussion about a professional graduate program designed for teacher's formation. ${ }^{4}$ The timing seems appropriate to go deeper with these reflections and to broaden our actions.

All of these efforts to move forward must be closely tied with the consolidation of Brazilian system of primary and secondary education. It is hard trying to predict the future, but we all agree that there is no future without good education.

\section{Joaquim A. Nóbrega JBCS Editor}

\section{References}

1. de Almeida, E. C. E.; Guimarães, J. A.; A pósgraduação e a evolução da produção científica brasileira; Editora SENAC, São Paulo, Brazil, 2013.

2. Wongtschowski, P.; J. Braz. Chem. Soc. 2012, 23, 1957.

3. Oliveira, F. C. C.; Personal Communication.

4. Pinto, A. C.; J. Braz. Chem. Soc. 2012, 23, 1410. 